\title{
The Impact of Monetary Policy on Bank Profitability and the Moderating Role of Funding Patterns in Vietnam
}

\author{
Van Dan Danga
}

\begin{abstract}
The study investigates the effect of monetary policy on bank profitability while also taking into account the moderating role of bank funding patterns. Uniquely, the study focuses on disaggregate components of bank profits in an environment containing various monetary policy tools. Using a dataset of commercial banks in Vietnam, the results show that monetary policy drives bank profitability asymmetrically. Concretely, interest rates (i.e., lending rates and policy rates) exert positive effects on net interest income, but negative impacts on non-interest income. For quantitative-based policy tools, including the central bank's security purchases and foreign exchange reserves, monetary policy is positively correlated with non-interest income but negatively associated with net interest income. The reaction of banks' net interest income to monetary policy adjustments is translated into overall bank profits. Further analysis indicates that the monetary policy/bank profitability nexus across different proxies is less pronounced at banks with more diversified funding patterns. This finding sheds light on prior arguments attributing financially weaker banks' greater sensitivity in facing monetary shocks to the limited alternative funding.
\end{abstract}

Keywords: Bank funding patterns; Bank profitability; Monetary policy; Net interest income; Non-interest income.

JEL Classification: E52, E58, G21

a Department of Finance, Banking University of Ho Chi Minh City, Vietnam. 36 Ton That Dam Street, Nguyen Thai Binh Ward, District 1, Ho Chi Minh City 700000, Vietnam. E-mail: dandv@buh.edu.vn, Orcid ID: https://orcid.org/0000-0001-5524-8765 


\section{Introduction}

Banks have always played an essential role in monetary policy transmission. During this process, banks' business outcomes are affected in many different ways. For example, the easing of a central bank's monetary policy means that enterprises have abundant access to funding at lower cost, thereby improving their performance and reducing bad debts to lending banks (Bernanke \& Gertler, 1995). However, it is also observed that there are costs in addition to the benefits of easing monetary policy, e.g., decreased interest rates hamper net interest margins (Samuelson, 1945). The mechanisms by which monetary policy influences banks is complicated in terms of theory, leading to ambiguity in profitability. It should also be emphasised that bank profits shape capital buffers, thereby defining bank safety and soundness key concerns of the economy. These facts mean that the effect of monetary policy on bank profits needs to be addressed.

The impact of monetary policy on bank profitability is a long-established concept in the literature. However, given considerable changes in global financial conditions, monetary policies and bank behaviours across countries, the investigation of this nexus has still been limited in scope and context so far. Scholars have often used only one single monetary policy indicator in their analyses, mostly short term interest rates, although many countries have added new monetary policy tools into their unconventional frameworks after the financial crisis of 2008 (Chen et al., 2017). In this regard, the effectiveness of different monetary tools is heterogeneous (Varlik \& Berument, 2017). Also, the components of bank income have not been carefully taken care of to accurately identify the "transmission channel" to overall bank profitability. This gap is partially filled by the recent attempts of Altavilla et al. (2018) for the Eurozone. However, clear-cut links between monetary policy and non-interest income have not been shown yet. Another important shortcoming is that prior studies have mainly focused on the leading advanced economies, but have disregarded emerging markets (see, for instance, Borio et al. (2017), Lambert and Ueda (2014) and Mamatzakis and Bermpei (2016), among others, who employ data from the United States [US] for their work). Taken together, more work is needed to draw a bigger and clearer picture of the present topic.

This study examines the effects of monetary policy on bank profitability in Vietnam for the period from 2007 to 2018. Going a step further than the 
well-known strand of research on credit portfolio performance changes with interest rate shocks, it breaks down bank revenue into net interest income and non-interest income, along with overall profits captured by returns on assets, to specifically figure out the transmission channel caused by different monetary tools. To this end, besides short term lending rates, this study also considers other essential tools as monetary policy indicators for regression analysis. Additionally, we are also interested in the heterogeneous effects of monetary policy on bank profits, according to a critical moderator - bank funding patterns. The theory shows that the bank funding determines the effectiveness of the transmission of monetary policy through bank credit channels (Bernanke \& Blinder, 1988; Bernanke \& Gertler, 1995). Funding elasticity is sometimes regarded as a way to interpret variations in bank profits (Hancock, 1985). Furthermore, existing documents have highlighted growing concerns that banks' responses to monetary policy shocks depend on their financial strengths, which are thought to be associated with access to alternative funding (see section 2 for a review). Thus, this study aims to empirically clarify the modifying role of bank funding patterns in the nexus between monetary policy and bank profits, thereby providing more insights into the present topic. While the fewer difficulties experienced by banks in obtaining funding have made lending less sensitive to monetary shocks, it is important to check if funding diversification diminishes the effects of monetary policy on bank profitability, which is mainly shaped by lending.

Vietnam provides a favourable environment for research, based on the following unique characteristics: (1) it is an emerging market, where monetary policy is established to serve a variety of goals. Great expectations are placed on the capacity of the banking system and lending - in the Vietnamese context, the capital market is relatively underdeveloped (Dang, 2019a; Vo, 2016); (2) the Vietnamese banking industry has undertaken comprehensive reforms during the last decade, such as increasing capital equity, privatisation of government-owned banks and shifting towards noninterest activities. However, several existing government-owned banks still dominate the market (Dang, 2019b); (3) the State Bank of Vietnam (SBV) simultaneously employs various tools to implement monetary policy. Some quantitative-based tools, such as securities trading and foreign exchange reserves, are used regularly. Uniquely, the required reserves and base interest rates are constant for long periods in Vietnam.

This study contributes to the literature in several ways. First, it explores 
an emerging market that has drawn little attention from academics on this topic. Thereby, the findings provide new insights for Vietnam, and potentially other emerging markets as well. In this vein, the study takes good advantage of an environment of multiple monetary policy tools, some of which (such as foreign exchange reserves and policy rates) are scarcely accounted for in other articles. In recent work, Dang and Dang (2020) focus on Vietnam's multiple-tool regime to explore how bank performance moderates the link between monetary policy and risk-taking by banks. Nevertheless, their goal is different from ours. Secondly, this study applies measures of bank profitability in different dimensions to determine the transmission channels as well as the asymmetric effects of monetary policy. It also enriches the extant literature by indicating the moderating role of bank funding patterns on the heterogeneous links between monetary policy and bank profits. Surprisingly, the influence of bank funding patterns on the transmission of monetary policy has been ignored in the literature.

\section{Literature Review}

\subsection{Monetary policy and components of bank profits}

The study deals with the literature pertaining to the effects of monetary policy, gauged by interest-rate and non-interest-rate tools, on the components of bank profits, measured by interest and non-interest income. Hence, the following part presents the different transmission channels examined in previous related works.

Having been long established, the impact of interest rates on net interest margins of banks has attracted the most attention from academia. A pioneer, Samuelson (1945), theorised that when interest rates drop, the gains from reduced deposit costs cannot compensate for the losses caused by reduced credit revenues, ultimately dragging net interest margins down. Likewise, Hancock (1985) suggests the positive effects of increased interest rates on net interest margins, relying on the notion that lending rates are more elastic than deposit rates. Many recent empirical findings support these arguments (Aydemir \& Ovenc, 2016; Claessens et al., 2018; English et al., 2018).

Regarding credit quality, lower interest rates from relaxed monetary policies might support borrowers' operations. To some authors, this improves compliance with credit commitments from borrowers and subsequently 
enhances the quality of bank assets, stabilises revenue and reduces costs for banks (Bernanke \& Gertler, 1995). In contrast, other authors have proposed a competing hypothesis where the easing of monetary policy may reduce the incentives of banks in screening their borrowers and loans (Dell'Ariccia et al., 2014; Maddaloni \& Peydró, 2011). This results in eroded credit quality, riskier portfolios and potential credit booms. From an empirical standpoint, Altavilla et al. (2018) indicate that higher interest rates are not necessarily correlated with better returns for banks.

A growing strand of literature has focused on the transmission of monetary policy through bank lending activities, or the "bank lending channel" for short. First proposed by Bernanke and Blinder (1988), the channel outlines how the tightening of monetary policy reduces loanable funds. Consequently, banks have to cut lending if they fail to substitute reduced funds promptly. Abundant research has verified the existence of the bank lending channel across the world (see Yang and Shao (2016) for a thorough review). Given that the number of loan and deposit transactions is directly linked to fees and commissions (a major portion of non-interest income), shrinking the credit portfolio as a result of monetary policy tightening tends to diminish non-interest income of banks.

Besides the effects on fees/commissions, changes in interest rates also alter the prices of financial assets held by banks. A common principle is that increased interest rates depress the prices of financial products. In some cases (e.g., with available securities for sales), those losses might be quickly reflected in accounting books, and thus decrease non-interest income. Moreover, it is worth noticing another potential channel which is also based on the trading of lower priced assets. In this regard, the demand for asset portfolio management through banks declines, thereby reducing revenue from fees/commissions (Albertazzi \& Gambacorta, 2010). Generally, the existing literature appears to have similar expectations about the adverse effects of increased interest rates on non-interest income. Borio et al. (2017) provide empirical evidence in favour of the negative impact of interest rates on non-interest income, using a large sample of 109 global banks, headquartered in 14 major developed markets.

Compared to interest rate tools, the effects of non-interest rate tools on banks' non-interest income are more ambiguous, as seen through financial assets trading. According to the portfolio rebalancing theory, when the central bank purchases financial assets on bank portfolios, asset prices 
potentially rise due to increased demands for asset trading (Tobin, 1969). Many authors have recently concurred with this mechanism, in the view that unconventional monetary policies of the central bank boost asset prices and thereby improve income from non-traditional banking activities (Borio \& Zhu, 2012). In contrast, the market may interpret the central bank's purchases as a negative outlook of the economy (Christensen \& Rudebusch, 2016). Such predictions depress the prices of financial assets and subsequently the profits of banks.

Another research focuses on US monetary policy, particularly the large-scale asset purchases by the Federal Reserve, suggesting a potential negative relationship between monetary policy and net interest margins. The transmission channel is that Federal purchases result in decreased long term rates and narrow the spread between deposit rates (federal fund rates) and lending rates (Gagnon et al., 2011). Due to the greater elasticity of lending rates, losses in interest revenue destroy gains in interest expenses, thereby reducing net interest margins. Among the rare empirical studies on unconventional monetary policy and bank profits are the works of Lambert and Ueda (2014) who use the ratio of central bank assets to gross domestic product (GDP), and Mamatzakis and Bermpei (2016), who employ central bank assets and excess reserves to show the negative nexus for US banks. However, from an international perspective, similar evidence from other markets is yet to be found, especially in emerging economies.

\subsection{The role of bank funding patterns}

The literature on monetary policy transmission has sometimes highlighted the role of bank funding patterns. According to the function of the bank lending channel, in periods of monetary policy tightening, banks are more likely to cut their credit supply aggressively if they cannot find alternative funding sources, e.g., by issuing debts and equity instruments (Bernanke \& Blinder, 1988). In other words, having various non-deposit funds helps banks comfortably cope with reduced deposits, thereby mitigating the impact of monetary policy shocks (Bernanke \& Gertler, 1995). From this point, bank funding patterns play a crucial role in shaping the effectiveness of the transmission of monetary policy.

Additionally, as shown in a vast majority of studies (e.g., Altunbaş et al., 2002; Gambacorta, 2005; Kishan \& Opiela, 2006), banks that are financially 
weaker (such as smaller, less liquid, and less capitalised banks) are more sensitive to such shocks. These banks are judged to be vulnerable by the market, thus resulting in their difficulty in accessing alternative funding sources. Gambacorta and Marques-Ibanez (2011) made the first attempt to incorporate market funding patterns into their empirical model which examined the functioning of the bank lending channel. Ultimately, they claim that it is this modifying factor that drives the strength of monetary policy transmission. From the perspective of a monetary policy/bank profitability nexus, the literature needs further evidence to directly shed light on the importance of bank funding patterns.

\section{Methodology and Data}

\subsection{Variables}

\subsubsection{Monetary policy indicators}

This study uses a variety of monetary policy indicators instead of focusing on only one single proxy, unlike most previous studies. The average short term lending rates are used here, which is also considered in other studies (e.g., Chen et al., 2017; Yang \& Shao, 2016), but only in the context that there is no consensus on which short term interest rates should be preferred for gauging monetary policy. Further, the paper approaches policy rates, including refinancing rates (for short term loans) and rediscount rates (for discounted valuable papers). As a lender of last resort, the SBV often uses these tools to provide short term financing to commercial banks. Lending and policy rates are obtained from the International Financial Statistics (IFS) of the International Monetary Fund (IMF) and the SBV respectively.

Besides adjusting interest rates, the SBV also has other important tools which it uses to regulate the domestic money supply in the economy. Thus, this study uses two more indicators: security sales/purchases via open market operations and foreign exchange interventions by the SBV. Inspired by previous studies on quantitative-based monetary policy tools, it is argued that the central bank's claims on domestic real non-financial sectors (relative to GDP) are a fitted proxy for the former (Lambert \& Ueda, 2014; Mamatzakis \& Bermpei, 2016), while foreign exchange reserves (as a share of GDP) are a straightforward measure of the latter (Chen et al., 2017). The data are 
obtained from the IFS and the Global Financial Development Database of the World Bank. All in all, the larger values of the interest rate indicators suggest monetary policy tightening, while conversely, the larger values of non-interest rate indicators imply monetary policy easing.

\subsubsection{Bank profitability, funding diversification, and other variables}

Taking a step further away from existing works, this study explores the impact of monetary policy on the breakdowns of bank profits. Therefore, it constructs three accounting profitability indicators - net returns, net interest income and net non-interest income - as ratios of total average assets to assess overall profits, lending profits and non-lending profits respectively, as standard practices in each dimension's literature.

With respect to the moderating condition of our main interest, the study approaches the Herfindahl-Hirschman index to describe the funding patterns in terms of diversification, as follows (see Nguyen, 2018; Vo, 2020):

$$
\text { FuDiv }=1-\sum_{i=1}^{6} x_{i}^{2}
$$

where $x_{i}$ is the share of each specific type of funding in total bank funding.

Based on the funding structure of Vietnamese banks, this paper divides total bank funding into six components: (1) debts from the government and central bank; (2) interbank deposits; (3) customer deposits; (4) equity capital; (5) issued securities; and (6) other funding sources. In theory, the HerfindahlHirschman index above is a well-established measure of concentration in assets or deposits markets. So, this study takes its reverse value (subtracted from one) to estimate funding diversification. This value ranges from 0 to 1 ; the higher the value, the more diversified the funding structure is. From the perspective of financial intermediation, which specialises in mobilising deposits to make loans, the higher value of the "FuDiv" variable also reveals that banks are less dependent on customer deposits.

This work belongs to a vast segment of research on the determinants of bank profitability, accounting for control variables that are commonly identified as key determinants in line with existing literature (Athanasoglou et al., 2008; Goddard et al., 2004). Bank-specific characteristics include bank size, capitalisation, liquidity position and riskiness. Critical macroeconomic 
factors are also controlled, namely, the annual growth rate of GDP and the annual rate of inflation.

\subsection{Model specifications}

This study begins by examining the direct impact of monetary policy on bank profits (without incorporating bank funding patterns) according to the following baseline model specification:

$$
\begin{aligned}
& \text { Profit }_{i, t}=\alpha_{0}+\alpha_{1} \times \text { Profit }_{i, t-1}+\alpha_{2} \times \text { Monetary }_{t-1}+\alpha_{3} \times \\
& \text { Bank_Control }_{i, t-1}+\alpha_{4} \times \text { Macro_Control }_{t-1}+\varepsilon_{i, t}
\end{aligned}
$$

where $i$ captures individual banks and $t$ denotes years. Profit represents measures of bank profitability. Alternative monetary policy indicators are expressed as Monetary. Bank_Control and Macro_Control include the bank-specific and macroeconomic factors as discussed above. The lagged dependent variable is inserted into the right-hand side of the equation to adopt the dynamic panel model.

To perform the regression, this study uses the system generalised method of moments (GMM) estimator that is compatible with the dynamic panel model (Arellano \& Bover, 1995; Blundell \& Bond, 1998). Following Roodman (2009), it uses the two-step procedure and limits the number of lags of instruments, thus avoiding the "too many instruments" problem. Then, two groups of diagnostic tests are performed to ensure the validity of estimates: the Hansen test for over-identification restrictions and the Arrelano-Bond test for second-order autocorrelation in the residuals.

As the next step, the paper examines whether and how the impact of monetary policy on bank profits is affected by the moderating role of bank funding patterns. To this end, the interaction terms are incorporated into the baseline model as follows:

$$
\begin{aligned}
& \text { Profit }_{i, t}=\alpha_{0}+\alpha_{1} \times \text { Profit }_{i, t-1}+\alpha_{2} \times \text { Monetary }_{t-1}+\alpha_{3} \times \\
& \text { Monetary }_{t-1} \times \text { FuDiv }_{i, t-1}+\alpha_{4} \times \text { Bank_Control }_{i, t-1}+\alpha_{5} \\
& \times \text { Macro_Control }_{t-1}+\varepsilon_{i, t}
\end{aligned}
$$

Monetary policy indicators interact alternately with the funding diversification variable. Consequently, the regression coefficient of the 
interaction term indicates the marginal effects of bank funding patterns in relation to the monetary policy/bank profitability nexus.

\subsection{Data}

This work accessed bank data through the annual financial reports published on the websites of commercial banks in Vietnam from 2007 to 2018, by manually collecting the required data for the variables. Due to missing data, the final sample contains 351 observations from 30 banks, making up about $90 \%$ of the system's total assets in any given year.

The summary statistics of the variables are shown in Table 1 . The profitability measures captured by the average return on assets (ROA), net interest income and non-interest income of the banking industry during the research period are $0.82 \%, 2.51 \%$, and $0.65 \%$ respectively. Their statistical distributions are highlighted by a wide range of extreme values and large standard deviations, underlying considerable variation in the profitability of banks. As for monetary policy indicators, similar patterns are shown, indicating considerable adjustment in the monetary policy of the SBV during the last decade. The level of funding diversification is not high, as illustrated by an average value of 0.49 , and also varies significantly between banks, suggested by the distribution of the funding variable.

Table 2 presents the correlation coefficient matrix for each pair of variables. The correlations between profitability measures are not high, implying that banks do not necessarily perform in the same manner for each business segment. In contrast, policy indicators show relatively high correlations, revealing that the SBV has actively and simultaneously coordinated tools to approach monetary targets. For the control variables, the preliminary results have raised concerns of the high correlations between (1) bank size and bank capitalization, as well as (2) inflation and monetary policy. As a result, the checks suggest that we avoid the joint inclusion of these variables, and we thus exclude inflation and bank capital variables in the regression models. 
Table 1: Summary Statistics

\begin{tabular}{lllllc}
\hline \multicolumn{1}{c}{ Variables } & Observations & Mean & $\begin{array}{l}\text { Standard } \\
\text { deviation }\end{array}$ & Min & Max \\
\hline Bank profitability measures & & & & & \\
ROA & 351 & 0.82 & 0.58 & 0.01 & 2.31 \\
NetII & 351 & 2.51 & 1.04 & 0.41 & 5.34 \\
NonII & 351 & 0.65 & 0.52 & -0.24 & 2.20 \\
\hline Monetary policy indicators & & & & & \\
Lend_r & 351 & 10.64 & 3.36 & 6.96 & 16.95 \\
Ref_r & 351 & 8.21 & 2.57 & 6.25 & 15.00 \\
Red_r & 351 & 6.05 & 2.71 & 3.50 & 13.00 \\
CBC & 351 & 1.45 & 0.92 & 0.42 & 3.66 \\
FXR & 351 & 17.9 & 5.40 & 9.99 & 30.32 \\
\hline Bank-specific characteristics & & & & & \\
Size & 351 & 13.86 & 0.55 & 12.71 & 15.00 \\
Capital & 351 & 10.39 & 5.45 & 4.38 & 29.31 \\
Liquidity & 351 & 17.80 & 10.76 & 5.03 & 48.89 \\
Risk & 351 & 1.26 & 0.57 & 0.25 & 2.78 \\
FuDiv & 351 & 0.49 & 0.12 & 0.21 & 0.71 \\
\hline Macroeconomic factors & & & & & \\
GDP & 351 & 6.18 & 0.62 & 5.24 & 7.13 \\
Inflation & 351 & 6.04 & 6.25 & 0.87 & 23.11 \\
\hline
\end{tabular}

Notes: The table presents the summary statistics of all variables employed in this study. ROA, NetII and NonII are measures of bank profitability, computed by the ratio of net returns, net interest income and net non-interest income to total average assets respectively. Lend_r, Ref_r, Red_r, CBC and $F X R$ are monetary policy indicators, captured by lending rates, refinance rates, rediscount rates, the SBV's claims on domestic real non-financial sectors/GDP, and the SBV's foreign exchange reserves/ GDP respectively. FuDiv is the proxy for bank funding patterns, calculated according to the reverse Hirschman-Herfindahl index. Size, Capital, Liquidity and Risk denote bank-specific characteristics, measured by the natural logarithm of bank assets (bank size), equity/total assets (bank capitalisation), liquid assets/total assets (bank liquidity position), and loan loss provisions/total gross loans (bank risk), respectively. GDP and Inflation are the annual growth rate of GDP and the annual rate of inflation respectively. 


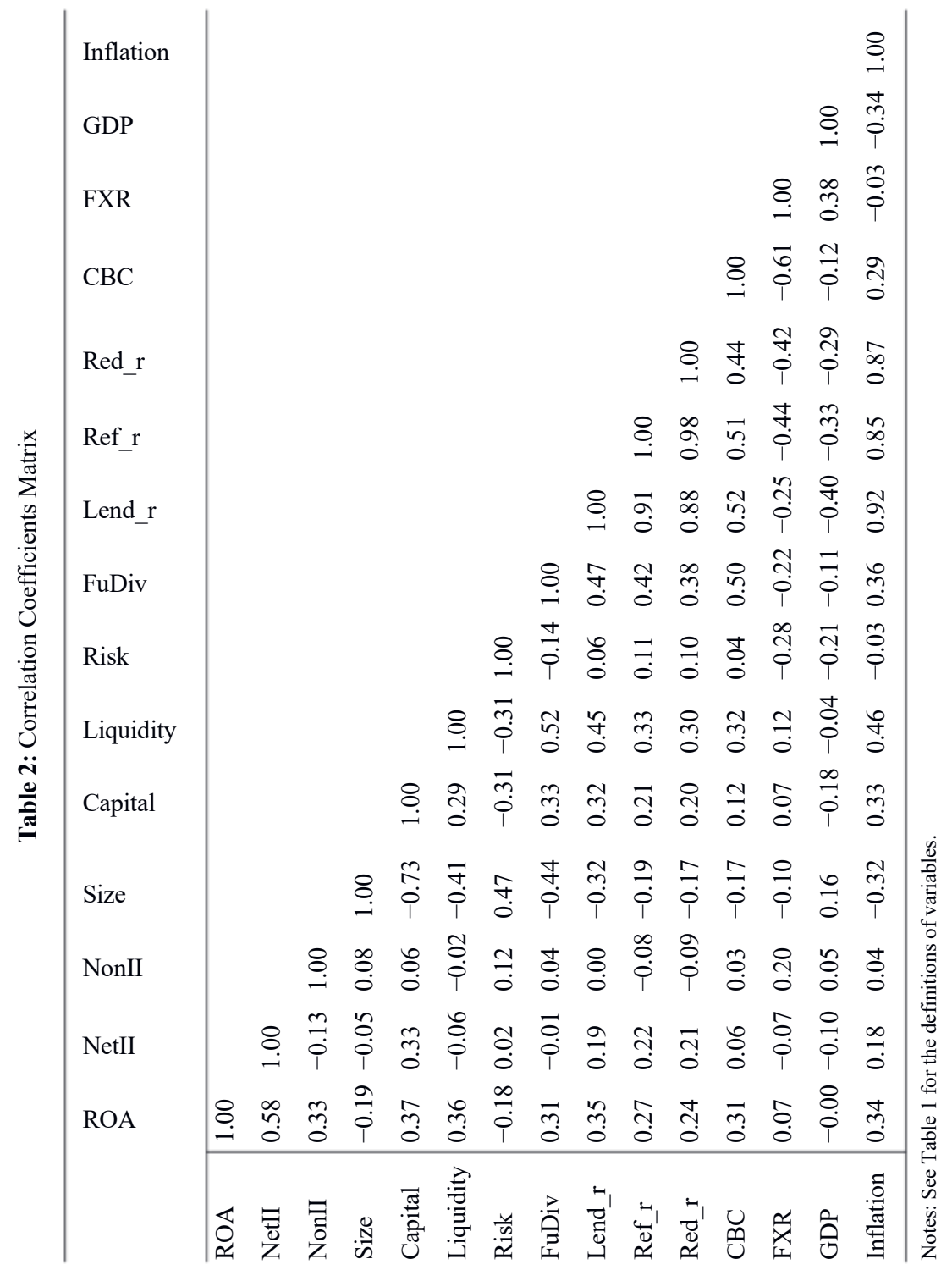




\section{Results and Discussion}

\subsection{Baseline estimation results}

The paper first presents the estimated results of the effects of monetary policy on bank profitability through the baseline models. In Table 3, the results show positive associations between net interest income and lending/ policy rates (columns 1-3); meanwhile, net interest income is negatively linked to SBV's assets and foreign exchange reserves (columns 4-5). The statistical significance is at the $1 \%$ level, thereby providing strong evidence confirming previous findings of positive impacts of increased interest rates on net interest income of global banks (Aydemir \& Ovenc, 2016; Claessens et al., 2018; English et al., 2018). These findings also support the negative relationship between unconventional monetary policy and net interest margins found in the US (Mamatzakis \& Bermpei, 2016), but through the analysis of the central bank's assets and foreign exchange reserves. In a nutshell, it seems that the credit portfolio of banks yield better outcomes in the event of monetary policy tightening.

Table 3: Monetary Policy and Bank Profitability Captured by Net Interest Income

\begin{tabular}{|c|c|c|c|c|c|}
\hline & (1) NetII & (2) NetII & (3) NetII & (4) NetII & (5) NetII \\
\hline \multicolumn{6}{|c|}{ Lagged dependent } \\
\hline \multirow[t]{2}{*}{ variable } & $0.609 * * *$ & $0.621 * * *$ & $0.631 * * *$ & $0.563 * * *$ & $0.576^{* * *}$ \\
\hline & $(0.036)$ & $(0.035)$ & $(0.035)$ & $(0.034)$ & $(0.043)$ \\
\hline \multirow[t]{2}{*}{ Lend_r } & $0.060 * * *$ & & & & \\
\hline & $(0.009)$ & & & & \\
\hline \multirow[t]{2}{*}{ Ref_r } & & $0.090 * * *$ & & & \\
\hline & & $(0.010)$ & & & \\
\hline \multirow[t]{2}{*}{ Red_r } & & & $0.080 * * *$ & & \\
\hline & & & $(0.009)$ & & \\
\hline \multirow[t]{2}{*}{$\mathrm{CBC}$} & & & & $-0.162 * * *$ & \\
\hline & & & & $(0.030)$ & \\
\hline \multirow[t]{2}{*}{ FXR } & & & & & $-0.012 * * *$ \\
\hline & & & & & $(0.004)$ \\
\hline \multirow[t]{2}{*}{ Size } & $0.249 * * *$ & $0.193 * * *$ & $0.214 * * *$ & $0.244 * * *$ & $0.249 * * *$ \\
\hline & $(0.053)$ & $(0.051)$ & $(0.048)$ & $(0.061)$ & $(0.066)$ \\
\hline
\end{tabular}




\begin{tabular}{llllll}
\hline & $(\mathbf{1})$ NetII & $\mathbf{( 2 )}$ NetII & $\mathbf{( 3 )}$ NetII & (4) NetII & (5) NetII \\
\hline Liquidity & $0.008^{* * *}$ & $0.006^{* *}$ & $0.008^{* * *}$ & $0.012^{* * *}$ & $0.015^{* * *}$ \\
& $(0.003)$ & $(0.003)$ & $(0.002)$ & $(0.002)$ & $(0.003)$ \\
Risk & -0.064 & -0.039 & -0.050 & -0.067 & -0.060 \\
& $(0.072)$ & $(0.070)$ & $(0.071)$ & $(0.071)$ & $(0.078)$ \\
GDP & $0.259^{* * *}$ & $0.231^{* * *}$ & $0.200^{* * *}$ & $0.197 * * *$ & $0.168^{* * *}$ \\
& $(0.042)$ & $(0.040)$ & $(0.041)$ & $(0.031)$ & $(0.030)$ \\
Observations & 321 & 321 & 321 & 321 & 321 \\
Banks & 30 & 30 & 30 & 30 & 30 \\
Instruments & 26 & 26 & 26 & 26 & 26 \\
AR(1) test & 0.000 & 0.000 & 0.000 & 0.000 & 0.000 \\
AR(2) test & 0.320 & 0.412 & 0.381 & 0.192 & 0.105 \\
Hansen test & 0.177 & 0.196 & 0.190 & 0.163 & 0.155 \\
\hline
\end{tabular}

Notes: The dependent variable is the ratio of net interest income to total assets (NetII). ***,** and $*$ denote the $1 \%, 5 \%$ and $10 \%$ levels of significance respectively. See Table 1 for the definitions of variables.

Turning to the regression results of non-interest income in Table 4, monetary policy across three proxies of interest rates exert detrimental effects on non-interest income (columns 1-3), while positive effects are found via monetary tools that alter money supply (columns 4-5). These findings are consistent with those obtained by Borio et al. (2017), who demonstrate that the increase in interest rates leads to a drop in non-interest income in the US banking sector, while Altavilla et al. (2018) obtain no clear-cut link in the Eurozone. Based on the established function of the bank lending channel, the increased interest rates could be interpreted as attenuating lending activities and thereby adversely affecting associated revenue from fees and commissions. Interestingly, the finding lends support to the previous argument which posits that monetary expansion contributes to increased prices of financial assets held by banks, and thus results in better gains in non-interest income. This study enriches the literature by providing rare empirical evidence, i.e., SBV's purchases of securities and foreign exchange reserves as monetary policy indicators. In general, a relaxed monetary policy benefits the non-interest income of banks. 
Table 4: Monetary Policy and Bank Profitability Captured by Non-interest Income

\begin{tabular}{|c|c|c|c|c|c|}
\hline & (1) NonII & (2) NonII & (3) NonII & (4) NonII & (5) NonII \\
\hline \multirow{2}{*}{$\begin{array}{l}\text { Lagged } \\
\text { dependent } \\
\text { variable }\end{array}$} & $0.417 * * *$ & $0.382 * * *$ & $0.394 * * *$ & $0.401 * * *$ & $0.380 * * *$ \\
\hline & $(0.022)$ & $(0.019)$ & $(0.020)$ & $(0.029)$ & $(0.026)$ \\
\hline \multirow[t]{2}{*}{ Lend_r } & $-0.016^{* * *}$ & & & & \\
\hline & $(0.003)$ & & & & \\
\hline \multirow[t]{2}{*}{ Ref_r } & & $-0.030 * * *$ & & & \\
\hline & & $(0.004)$ & & & \\
\hline \multirow[t]{2}{*}{ Red_r } & & & $-0.031 * * *$ & & \\
\hline & & & $(0.004)$ & & \\
\hline \multirow[t]{2}{*}{$\mathrm{CBC}$} & & & & $0.038 * * *$ & \\
\hline & & & & $(0.010)$ & \\
\hline \multirow[t]{2}{*}{ FXR } & & & & & $0.028 * * *$ \\
\hline & & & & & $(0.003)$ \\
\hline \multirow[t]{2}{*}{ Size } & 0.063 & $0.062 * *$ & $0.068 * *$ & $0.114 * * *$ & $0.081 * * *$ \\
\hline & $(0.039)$ & $(0.027)$ & $(0.028)$ & $(0.040)$ & $(0.027)$ \\
\hline \multirow[t]{2}{*}{ Liquidity } & $0.004 * * *$ & $0.003 *$ & $0.003 *$ & $0.003 * *$ & $0.004 * *$ \\
\hline & $(0.001)$ & $(0.002)$ & $(0.002)$ & $(0.001)$ & $(0.002)$ \\
\hline \multirow[t]{2}{*}{ Risk } & 0.004 & 0.014 & 0.010 & -0.052 & 0.003 \\
\hline & $(0.027)$ & $(0.026)$ & $(0.026)$ & $(0.034)$ & $(0.024)$ \\
\hline \multirow[t]{2}{*}{ GDP } & $0.063 * * *$ & $0.094 * * *$ & $0.097 * * *$ & 0.007 & -0.003 \\
\hline & $(0.019)$ & $(0.025)$ & $(0.026)$ & $(0.011)$ & $(0.016)$ \\
\hline Observations & 321 & 321 & 321 & 321 & 321 \\
\hline Banks & 30 & 30 & 30 & 30 & 30 \\
\hline Instruments & 26 & 25 & 25 & 26 & 25 \\
\hline $\mathrm{AR}(1)$ test & 0.001 & 0.002 & 0.002 & 0.001 & 0.002 \\
\hline $\mathrm{AR}(2)$ test & 0.109 & 0.140 & 0.132 & 0.104 & 0.111 \\
\hline Hansen test & 0.138 & 0.140 & 0.147 & 0.191 & 0.209 \\
\hline
\end{tabular}

Notes: The dependent variable is the ratio of net non-interest income to total assets (NonII). ${ }^{* *},{ }^{* *}$ and $*$ denote the $1 \%, 5 \%$ and $10 \%$ levels of significance respectively. See Table 1 for the definitions of variables. 
Table 5 displays the overall effects of monetary policy on bank profits, which are captured by the net return on assets. Based on the above results, one could infer that the positive impact of interest rates on net interest income overwhelms the negative impact on non-interest income, as evidenced by the significantly positive association between interest rates and ROA (columns 1-3). Similarly, the adverse effects on the net interest income seem to be stronger and cause a significantly negative link between the CBC and ROA variables (column 4), or they at least neutralise the surge of noninterest income (column 5). These findings are relevant in the context of the Vietnamese banking industry, where net interest income accounts for a major part of total revenue. This does not only support Mamatzakis and Bermpei (2016) findings, who revealed negative links between unconventional monetary policy and bank performance (with ROA/return on equity as a proxy), but also complement their work by breaking down overall profits into two components, net- and non-interest income, to offer more insights into the transmission channels.

Table 5: Monetary Policy and Bank Profitability Captured by Return on Assets

\begin{tabular}{|c|c|c|c|c|c|}
\hline & (1) ROA & (2) ROA & (3) ROA & (4) ROA & (5) ROA \\
\hline \multirow{2}{*}{$\begin{array}{l}\text { Lagged } \\
\text { dependent } \\
\text { variable }\end{array}$} & $0.500 * * *$ & $0.502 * * *$ & $0.517 * * *$ & $0.480 * * *$ & $0.539 * * *$ \\
\hline & $(0.033)$ & $(0.032)$ & $(0.028)$ & $(0.034)$ & $(0.034)$ \\
\hline \multirow[t]{2}{*}{ Lend_r } & $0.012 * * *$ & & & & \\
\hline & $(0.004)$ & & & & \\
\hline \multirow[t]{2}{*}{ Ref_r } & & $0.021 * * *$ & & & \\
\hline & & $(0.006)$ & & & \\
\hline \multirow[t]{2}{*}{ Red_r } & & & $0.018 * * *$ & & \\
\hline & & & $(0.006)$ & & \\
\hline \multirow[t]{2}{*}{$\mathrm{CBC}$} & & & & $-0.058 * * *$ & \\
\hline & & & & $(0.011)$ & \\
\hline \multirow[t]{2}{*}{ FXR } & & & & & -0.003 \\
\hline & & & & & $(0.002)$ \\
\hline \multirow[t]{2}{*}{ Size } & 0.021 & 0.024 & 0.028 & $0.032 *$ & 0.015 \\
\hline & $(0.023)$ & $(0.021)$ & $(0.021)$ & $(0.017)$ & $(0.021)$ \\
\hline \multirow[t]{2}{*}{ Liquidity } & $0.009 * * *$ & $0.009 * * *$ & $0.009 * * *$ & $0.008 * * *$ & $0.010 * * *$ \\
\hline & $(0.001)$ & $(0.001)$ & $(0.001)$ & $(0.001)$ & $(0.001)$ \\
\hline
\end{tabular}




\begin{tabular}{llllll}
\hline & (1) ROA & (2) ROA & (3) ROA & (4) ROA & (5) ROA \\
\hline Risk & 0.025 & 0.020 & 0.022 & 0.014 & 0.031 \\
& $(0.028)$ & $(0.026)$ & $(0.026)$ & $(0.026)$ & $(0.029)$ \\
GDP & $0.129 * * *$ & $0.124 * * *$ & $0.116^{* * *}$ & $0.107^{* * *}$ & $0.122^{* * *}$ \\
& $(0.014)$ & $(0.013)$ & $(0.013)$ & $(0.018)$ & $(0.014)$ \\
Observations & 321 & 321 & 321 & 321 & 321 \\
Banks & 30 & 30 & 30 & 30 & 30 \\
Instruments & 26 & 26 & 26 & 26 & 26 \\
AR(1) test & 0.003 & 0.003 & 0.002 & 0.003 & 0.003 \\
AR(2) test & 0.204 & 0.353 & 0.300 & 0.239 & 0.216 \\
Hansen test & 0.281 & 0.299 & 0.288 & 0.260 & 0.267 \\
\hline
\end{tabular}

Notes: The dependent variable is the rate of ROA. ***,** and $*$ denote the $1 \%, 5 \%$ and $10 \%$ levels of significance respectively. See Table 1 for the definitions of variables.

\subsection{The moderating role of bank funding patterns in the augmented model specification}

This subsection presents empirical results on how the marginal effect of monetary policy on bank profits varies with the levels of funding diversification. As seen in Table 6, the standalone effects of monetary policy indicators on bank profitability measures are unchanged, as previously observed in the baseline analysis. Further, all extended regressions indicate an interesting mechanism in common: the sign of the interaction terms (positive/negative) is always the opposite of the standalone monetary policy indicators. More precisely, using the lending and policy rates, the estimates indicate positive interaction terms in the non-interest income function (columns 1-3) and negative interaction terms in the net interest income equation (columns 6-8), given that the coefficients of monetary policy variables are negatively and positively linked to non-interest and net interest income respectively. Most findings are statistically significant, suggesting that funding diversification diminishes the effects of monetary policy on bank profits. Several possible explanations emerge. First, the availability of alternative funds reduces banks' sensitivity to monetary policy adjustments (Bernanke \& Gertler, 1995). Second, banks with more diversified funding patterns mitigate dependence on deposit funding sources, most of which are demand and transaction deposits (Samuelson, 1945). This means that such 


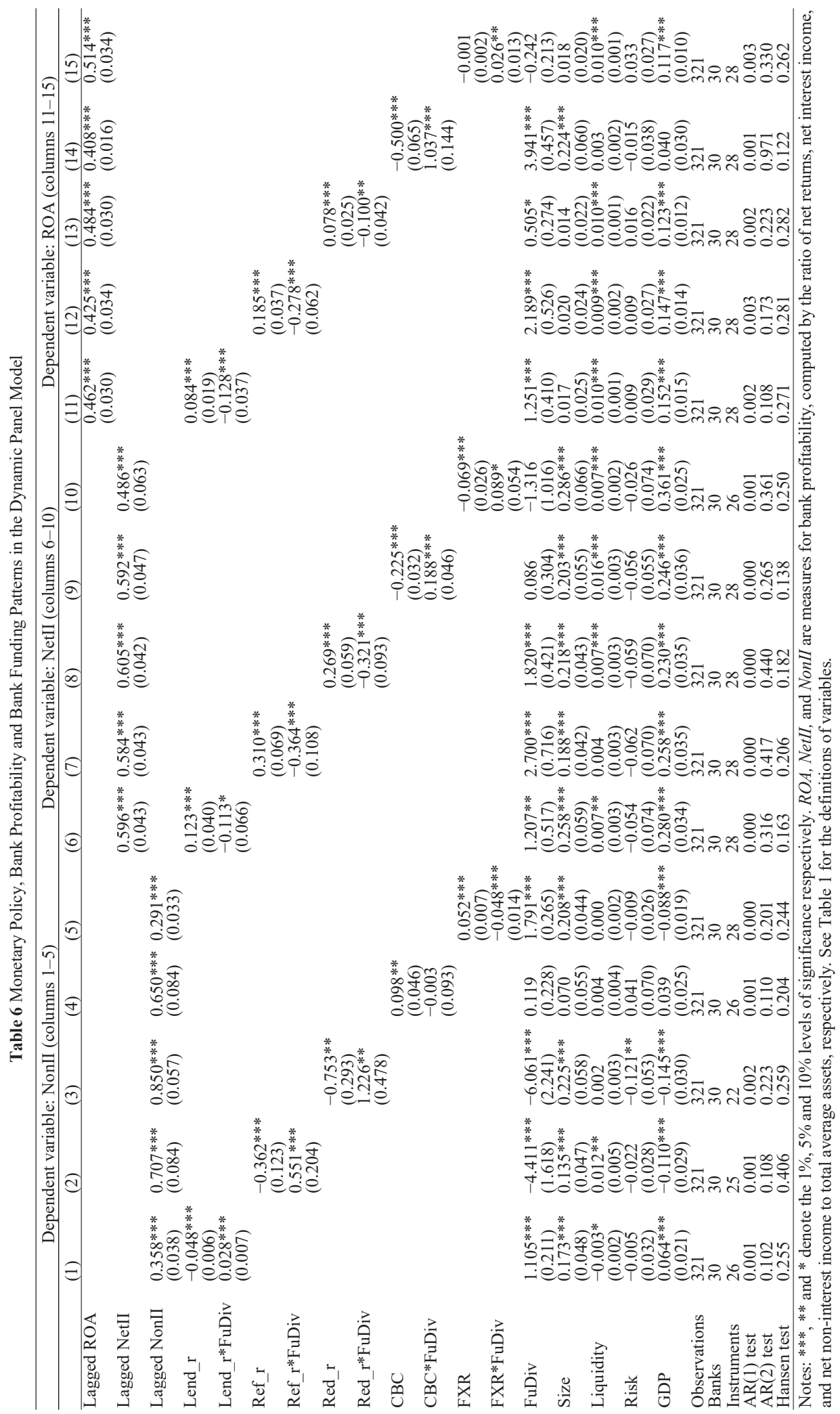


banks tend to have more higher-cost funding sources, thus increasing the elasticity of bank funding costs in response to changes in monetary policy. Third, diversifying from deposit funding (which is covered by insurance schemes) makes banks more prudent with their investment portfolios in response to monetary shocks (Demirgüç-Kunt \& Kane, 2002).

Although not reach high levels of statistical significance, the interaction terms using non-interest rate policy tools still generate the same patterns. Individually, the significant result observed in column 9 strongly suggests that the impact on net interest income from SBV's securities trading is weaker at banks with diversified funding sources. This funding diversification creates more flexibility in terms of these banks' financial asset transactions with the SBV, thereby slightly decreasing the losses of loan portfolios in the context of easing monetary policy. Once again, the dominant effect on net interest income seems to be shifted to return on assets, thus leading to the mitigated impact of monetary policy on overall bank profits (columns 11-15).

\subsection{Robustness checks}

This subsection elaborates additional checks to determine whether or not the robustness of findings holds with different regression designs. First, the least squares dummy variable corrected (LSDVC) estimator as an alternative technique to validate the GMM results (Bruno, 2005) is used. In the literature, the LSDVC estimator is employed as an efficient alternative to the dynamic system GMM estimator; it is robust, thus providing consistent and efficient estimates. Besides, this study also changes the econometric methodology by using the fixed effects model with Driscoll-Kraay standard errors (Hoechle, 2007).

As for the next procedure, this study replaces the funding diversification variable with a measure which suggests the proportion of deposits in total bank funding. This new proxy more directly reflects the level of dependence on deposits at banks. To facilitate the interpretation and comparison of results, the alternative reflective measure NonDep is defined by the ratio of non-deposit funding to total bank funding.

The regressions (with a full set of initial and alternative variables) are repeated using both the LSDVC estimator and fixed effects regressions using Driscoll-Kraay standard errors. Most key findings remain unchanged, thereby verifying the robustness of the links found in this study. This paper only reports the main results based on the LSDVC estimator with the funding 


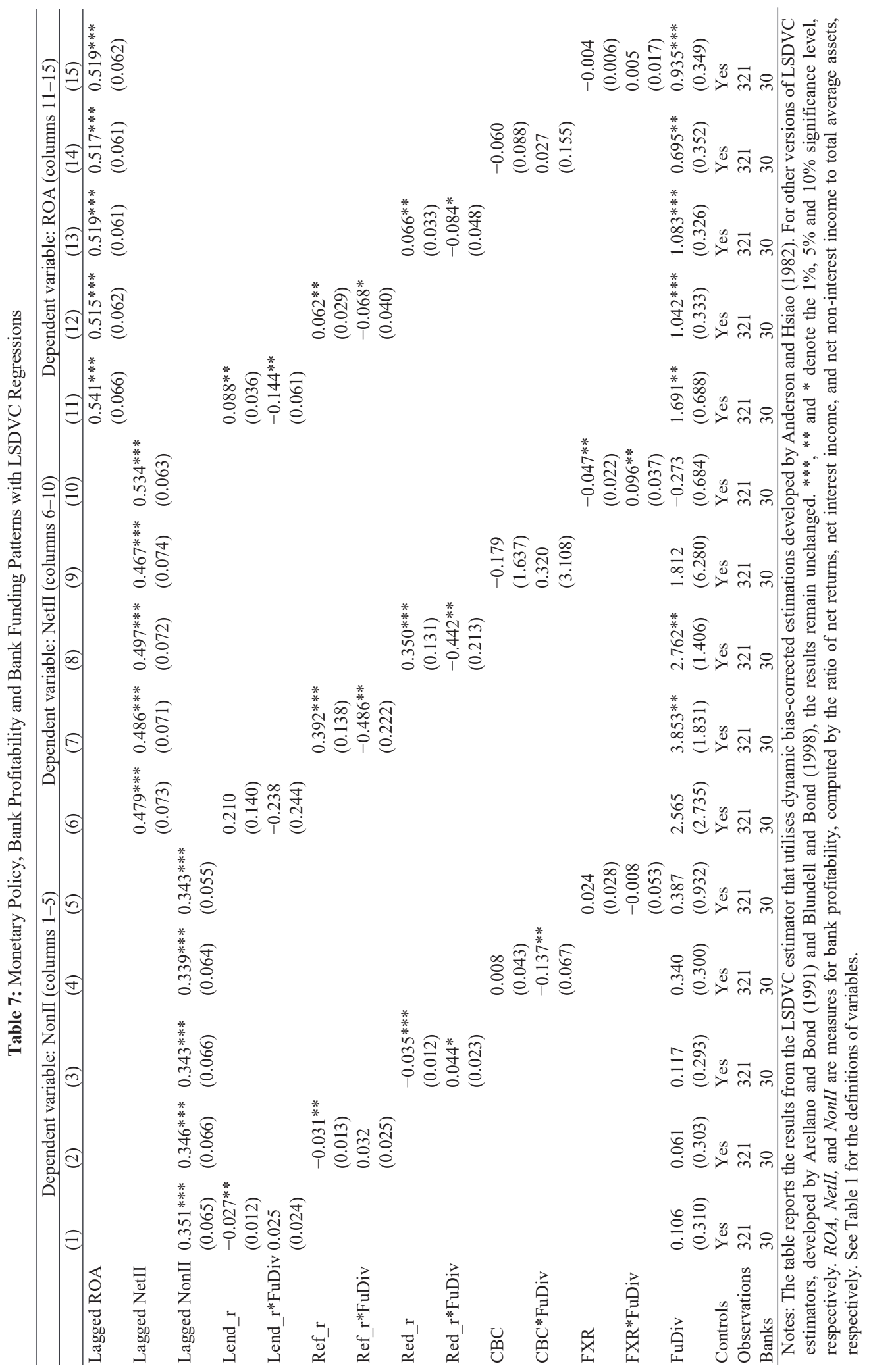




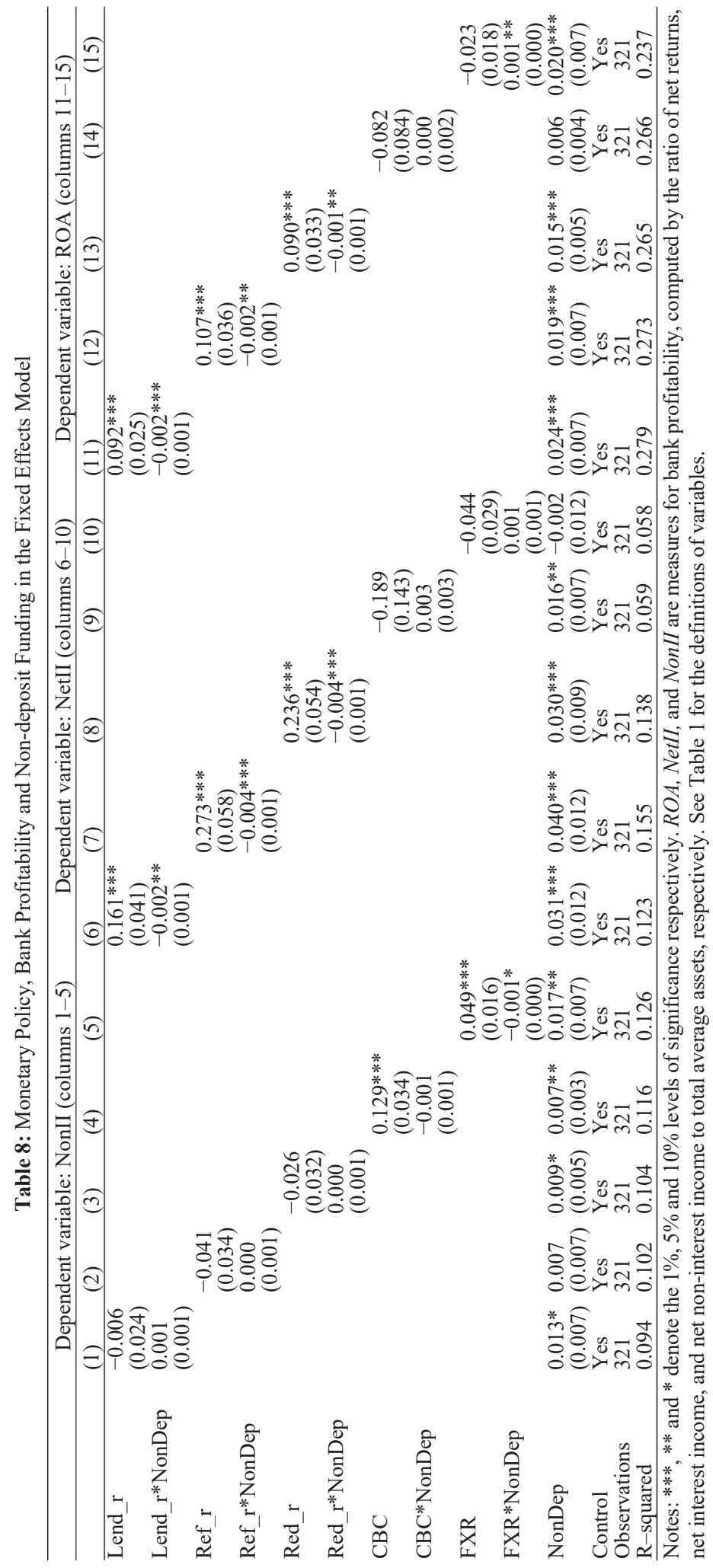


diversification measure (Table 7) and fixed effect regressions with the nondeposit funding variable (Table 8).

\section{Conclusions}

The primary finding is that monetary policy, across different choices of indicators, induces significant impacts on banks' overall profits, as observed by the net return on assets in Vietnam from 2007 to 2018. After breaking down bank profits into specific income components, it is observed that interest rates (lending and policy rates) exert positive effects on net interest income but negative impacts on non-interest income. Besides, using other policy tools gauged by SBV's assets and foreign exchange reserves, this study finds that monetary policy is significantly positively correlated with non-interest income but negatively associated with net interest income. Complementing the related paper by Mamatzakis and Bermpei (2016), the findings enrich the literature, by using quantitative-based tools that alter liquidity injection. Overall, the findings also confirm that net interest income is translated into overall returns in response to changes in monetary policy.

The second major finding is the moderating role of bank funding patterns on the relationship between monetary policy and bank profitability. A higher diversification level of funding sources diminishes the effects of monetary policy on bank profits, as captured by various disaggregated components. These findings firmly hold across multiple indicators of monetary policy and bank funding measures in alternative economic methodologies. Notably, they are most explicitly pronounced when central banks change interest rates and thereby drive net interest income as well as overall profits of banks.

The paper provide some insightful policy implications. Given the finding that monetary policy affects bank profits in multiple dimensions, monetary policymakers should pay close attention to bank performance, while bank managers need to consider transmission mechanisms carefully under such policies. In this vein, the concept that all different monetary policy tools appear to induce substantial effects on bank output needs to be considered in emerging markets. Besides, according to the heterogeneity of the monetary policy/bank profit nexus, this work calls for policy frameworks that look into bank funding patterns to ensure informed decisions. For instance, we found that the impact of monetary policy on bank profitability is mitigated by funding diversification. 


\section{References}

Albertazzi, U., \& Gambacorta, L. (2010). Bank profitability and taxation. Journal of Banking and Finance, 34(11), 2801-2810. https://doi. org/10.1016/j.jbankfin.2010.06.003

Altavilla, C., Boucinha, M., \& Peydró, J.-L. (2018). Monetary policy and bank profitability in a low interest rate environment. Economic Policy, 33(96), 531-586. https://doi.org/10.1093/epolic/eiy013

Altunbaş, Y., Fazylov, O., \& Molyneux, P. (2002). Evidence on the bank lending channel in Europe. Journal of Banking and Finance, 26(11), 2093-2110. https://doi.org/10.1016/S0378-4266(02)00201-7

Anderson, T. W., \& Hsiao, C. (1982). Formulation and estimation of dynamic models using panel data. Journal of Econometrics, 18(1), 47-82. https://doi.org/10.1016/0304-4076(82)90095-1

Arellano, M., \& Bond, S. (1991). Some tests of specification for panel data: Monte Carlo evidence and an application to employment equations. The Review of Economic Studies, 58(2), 277-297. https://doi. org $/ 10.2307 / 2297968$

Arellano, M., \& Bover, O. (1995). Another look at the instrumental variable estimation of error-components models. Journal of Econometrics, 68(1), 29-51. https://doi.org/10.1016/0304-4076(94)01642-D

Athanasoglou, P. P., Brissimis, S. N., \& Delis, M. D. (2008). Bank-specific, industry-specific and macroeconomic determinants of bank profitability. Journal of International Financial Markets, Institutions and Money, 18(2), 121-136. https://doi.org/10.1016/j.intfin.2006.07.001

Aydemir, R., \& Ovenc, G. (2016). Interest rates, the yield curve and bank profitability in an emerging market economy. Economic Systems, 40(4), 670-682. https://doi.org/10.1016/j.ecosys.2016.04.003

Bernanke, B. S., \& Blinder, A. S. (1988). Credit, money, and aggregate demand. American Economic Review, 78, 435-439. https://doi. org/10.1016/S0197-2510(11)70055-9

Bernanke, B. S., \& Gertler, M. (1995). Inside the black box: The credit channel of monetary policy transmission. Journal of Economic Perspectives, 9(4), 27-48. https://doi.org/10.1257/jep.9.4.27

Blundell, R., \& Bond, S. (1998). Initial conditions and moment restrictions in dynamic panel data models. Journal of Econometrics, 87(1), 115-143. https://doi.org/10.1016/S0304-4076(98)00009-8 
Borio, C., Gambacorta, L., \& Hofmann, B. (2017). The influence of monetary policy on bank profitability. International Finance, 20(1), 48-63. https://doi.org/10.1111/infi.12104

Borio, C., \& Zhu, H. (2012). Capital regulation, risk-taking and monetary policy: A missing link in the transmission mechanism? Journal of Financial Stability, 8(4), 236-251. https://doi.org/10.1016/j. jfs.2011.12.003

Bruno, G. S. F. (2005). Estimation and inference in dynamic unbalanced panel-data models with a small number of individuals. Stata Journal, 5(4), 473-500. https://doi.org/10.1177/1536867x0500500401

Chen, M., Wu, J., Jeon, B. N., \& Wang, R. (2017). Monetary policy and bank risk-taking: Evidence from emerging economies. Emerging Markets Review, 31, 116-140. https://doi.org/10.1016/j.ememar.2017.04.001

Christensen, J. H. E., \& Rudebusch, G. D. (2016). Modeling yields at the zero lower bound: Are shadow rates the solution? Advances in Econometrics, 35, 75-125. https://doi.org/10.1108/S0731905320150000035003

Claessens, S., Coleman, N., \& Donnelly, M. (2018). "Low-For-Long” interest rates and banks' interest margins and profitability: Cross-country evidence. Journal of Financial Intermediation, 35, 1-16. https://doi. org/10.1016/j.jfi.2017.05.004

Dang, V. D. (2019a). The effects of loan growth on bank performance: Evidence from Vietnam. Management Science Letters, 9(6), 899-910. https://doi.org/10.5267/j.msl.2019.2.012

Dang, V. D. (2019b). The risk-return trade-off of liquidity positions: Evidence from Vietnamese banking system. International Journal of Monetary Economics and Finance, 12(5), 390-406. https://doi. org/10.1504/IJMEF.2019.102954

Dang, V. D., \& Dang, V. C. (2020). The conditioning role of performance on the bank risk-taking channel of monetary policy: Evidence from a multiple-tool regime. Research in International Business and Finance, 54. https://doi.org/10.1016/j.ribaf.2020.101301

Dell'Ariccia, G., Laeven, L., \& Marquez, R. (2014). Real interest rates, leverage, and bank risk-taking. Journal of Economic Theory, 149(1), 65-99. https://doi.org/10.1016/j.jet.2013.06.002

Demirgüç-Kunt, A., \& Kane, E. J. (2002). Deposit insurance around the globe: Where does it work? Journal of Economic Perspectives, 16(2), 
175-195. https://doi.org/10.1257/0895330027319

English, W. B., Van den Heuvel, S. J., \& Zakrajšek, E. (2018). Interest rate risk and bank equity valuations. Journal of Monetary Economics, 98, 80-97. https://doi.org/10.1016/j.jmoneco.2018.04.010

Gagnon, J., Raskin, M., Remache, J., \& Sack, B. (2011). The financial market effects of the federal reserve's large-scale asset purchases. International Journal of Central Banking, 7(1), 3-43.

Gambacorta, L. (2005). Inside the bank lending channel. European Economic Review, 49(7), 1737-1759. https://doi.org/10.1016/j. euroecorev.2004.05.004

Gambacorta, L., \& Marques-Ibanez, D. (2011). The bank lending channel: Lessons from the crisis. Economic Policy, 26(66), 135-182. https://doi. org/10.1111/j.1468-0327.2011.00261.x

Goddard, J., Molyneux, P., \& Wilson, J. O. S. (2004). The profitability of European banks: A cross-sectional and dynamic panel analysis. Manchester School, 72(3), 363-381. https://doi.org/10.1111/j.14679957.2004.00397.x

Hancock, D. (1985). Bank profitability, interest rates, and monetary policy. Journal of Money, Credit and Banking, 17(2), 189-202. https://doi. org/10.2307/1992333

Hoechle, D. (2007). Robust standard errors for panel regressions with cross-sectional dependence. Stata Journal, 7(3), 281-312. https://doi. org/10.1177/1536867x0700700301

Kishan, R. P., \& Opiela, T. P. (2006). Bank capital and loan asymmetry in the transmission of monetary policy. Journal of Banking and Finance, 30(1), 259-285. https://doi.org/10.1016/j.jbankfin.2005.05.002

Lambert, F., \& Ueda, K. (2014). The effects of unconventional monetary policies on bank soundness. In IMF Working Papers No 152. https://doi. org/10.5089/9781498363563.001

Maddaloni, A., \& Peydró, J. L. (2011). Bank risk-taking, securitization, supervision, and low interest rates: Evidence from the Euro-area and the U.S. lending standards. Review of Financial Studies, 24(6), 2121-2165. https://doi.org/10.1093/rfs/hhr015

Mamatzakis, E., \& Bermpei, T. (2016). What is the effect of unconventional monetary policy on bank performance? Journal of International Money and Finance, 67, 239-263. https://doi.org/10.1016/j.jimonfin.2016.05.005 Nguyen, T. L. A. (2018). Diversification and bank efficiency in six ASEAN 
countries. Global Finance Journal, 37, 57-78. https://doi.org/10.1016/j. gfj.2018.04.004

Roodman, D. (2009). How to do xtabond2: An introduction to difference and system GMM in Stata. Stata Journal, 9(1), 86-136. https://doi. org/10.1177/1536867x0900900106

Samuelson, P. A. (1945). The effect of interest rate increases on the banking system. American Economic Review, 35, 16-27.

Tobin, J. (1969). A general equilibrium approach to monetary theory. Journal of Money, Credit and Banking, 1(1), 15-29. https://doi. org/10.2307/1991374

Varlik, S., \& Berument, M. H. (2017). Multiple policy interest rates and economic performance in a multiple monetary-policy-tool environment. International Review of Economics and Finance, 52, 107-126. https:// doi.org/10.1016/j.iref.2017.10.004

Vo, X. V. (2016). Finance in Vietnam-an overview. Afro-Asian Journal of Finance and Accounting, 6(3), 202-209. https://doi.org/10.1504/ AAJFA.2016.079311

Vo, X. V. (2020). The Role of Bank Funding Diversity: Evidence from Vietnam. International Review of Finance, 20(2), 529-536. https://doi. org/10.1111/irfi. 12215

Yang, J., \& Shao, H. (2016). Impact of bank competition on the bank lending channel of monetary transmission: Evidence from China. International Review of Economics and Finance, 43, 468-481. https:// doi.org/10.1016/j.iref.2015.12.008 